$12-2016$

\title{
Punishing Genocide: A Comparative Empirical Analysis of Sentencing Laws and Practices at the International Criminal Tribunal for Rwanda (ICTR), Rwandan Domestic Courts, and Gacaca Courts
}

\author{
Barbora Hola \\ VU University Amsterdam, The Netherlands \\ Hollie Nyseth Brehm \\ The Ohio State University
}

Follow this and additional works at: https://digitalcommons.usf.edu/gsp

\author{
Recommended Citation \\ Hola, Barbora and Nyseth Brehm, Hollie (2016) "Punishing Genocide: A Comparative Empirical Analysis of \\ Sentencing Laws and Practices at the International Criminal Tribunal for Rwanda (ICTR), Rwandan \\ Domestic Courts, and Gacaca Courts," Genocide Studies and Prevention: An International Journal: Vol. 10: \\ Iss. 3: 59-80. \\ DOI: \\ http://doi.org/10.5038/1911-9933.10.3.1428
}

Available at: https://digitalcommons.usf.edu/gsp/vol10/iss3/7

This Articles is brought to you for free and open access by the Open Access Journals at Digital Commons @ University of South Florida. It has been accepted for inclusion in Genocide Studies and Prevention: An International Journal by an authorized editor of Digital Commons @ University of South Florida. For more information, please contact digitalcommons@usf.edu. 


\section{Punishing Genocide: A Comparative Empirical Analysis of Sentencing Laws and Practices at the International Criminal Tribunal for Rwanda (ICTR), Rwandan Domestic Courts, and Gacaca Courts}

\section{Acknowledgements}

The research of the first author was conducted as part of a research project on Vertical (In)consistency of International Sentencing funded by the Netherlands Organization for Scientific Research (NWO) within its Innovational Research Incentives Scheme Veni. For more information on the Innovational Research Incentives Scheme Veni, please visit https://www.nwo.nl/en/funding/our-funding-instruments/nwo/ innovational-research-incentives-scheme/veni/index.html. 


\title{
Punishing Genocide: A Comparative Empirical Analysis of Sentencing Laws and Practices at the International Criminal Tribunal for Rwanda (ICTR), Rwandan Domestic Courts, and Gacaca Courts
}

\author{
Barbora Hola \\ VU University Amsterdam \\ Amsterdam, The Netherlands \\ Hollie Nyseth Brehm \\ The Ohio State University \\ Columbus, Ohio, USA
}

\begin{abstract}
This article compares sentencing of those convicted of participation in the 1994 genocide in Rwanda. With over one million people facing trial, Rwanda constitutes the world's most comprehensive case of criminal accountability after genocide and presents an important case study of punishing genocide. Criminal courts at three different levels - international, domestic, and local-sought justice in the aftermath of the violence. In order to compare punishment at each level, we analyze an unprecedented database of sentences given by the ICTR, the $R$ wandan domestic courts, and Rwanda's Gacaca courts. The analysis demonstrates that sentencing varied across the three levels-ranging from limited time in prison to death sentences. We likewise find that sentencing at the domestic courts appears to have been comparatively more serious than sentencing at the ICTR and at the Gacaca courts, which calls into question the consistency of sentences across levels of justice and should be explored in future research.
\end{abstract}

Keywords: punishment, genocide, Rwanda, ICTR, Gacaca, sentencing, transitional justice

\section{Introduction}

On April 6, 1994, unknown assailants assassinated Rwandan President Juvénal Habyarimana by shooting down his plane. The plane crash and the resulting assassination served as what many experts term the "genocidal spark," and extreme violence subsequently unfolded across the country. The violence largely subsided by mid-July, when the Tutsi-led Rwanda Patriotic Front brought an end to the genocide. Within just a few months, between 500,000 and one million people had been killed, hundreds of thousands of people had been victims of sexual violence, and millions were displaced. While political elites within the Hutu-dominated government orchestrated and led this violence, many civilians also took part in the genocide. By some estimates, several hundred thousand Rwandan civilians participated in the killings, ${ }^{1}$ and an even greater number participated in the destruction of property. ${ }^{2}$

In the aftermath of the genocide, Rwanda and the international community grappled with how to bring suspected perpetrators to justice. In November 1994, the United Nations Security Council issued a resolution creating the International Criminal Tribunal for Rwanda (ICTR) in order to try those responsible for war crimes, crimes against humanity, and genocide. Due to limited resources and a very limited mandate, however, the ICTR was unable to prosecute the hundreds of thousands of people suspected of involvement in the genocide. Instead, the Tribunal tried only a limited number of relatively high-ranking individuals, such as representatives of the government or powerful clergy and business elites. This highly selective focus meant that the new government of Rwanda was left with hundreds of thousands of suspected génocidaires within the country. After deliberation, the Rwandan government decided to try these individuals through two separate court systems: 1) the existing domestic court system, which was progressively meant to try suspected participants who had relatively high levels of responsibility, and 2) a local court

\footnotetext{
${ }^{1}$ Scott Straus, "How Many Perpetrators Were There in the Rwandan Genocide? An Estimate," Journal of Genocide Research 6, no. 1 (2004), 95

${ }^{2}$ Hollie Nyseth Brehm, Christopher Uggen, and Jean-Damascéne Gasanabo, “Genocide, Justice, and Rwanda's Gacaca Courts," Journal of Contemporary Criminal Justice 30, no. 3 (2014), 340.
} 
system called Inkiko Gacaca, which was given authority to try the majority of participants in local trials throughout the country.

This article compares sentencing of those convicted of genocide and other crimes at these three different judicial systems - the ICTR, the Rwandan domestic courts, and the Rwandan Gacaca courts. With approximately one million people facing trial, Rwanda arguably constitutes the world's most comprehensive case of criminal accountability after genocide. It thus presents an important case study of punishment following genocide. Yet, to our knowledge, few studies compare these three court systems, ${ }^{3}$ and no studies examine sentencing laws and practices across the three systems.

In what follows, we assess sentencing laws and practices at the ICTR, the Rwandan domestic courts, and the Gacaca courts through the analysis of an original, unprecedented database. We begin by briefly introducing the three court systems and outlining their development over time. We then describe the database, its limitations, and the descriptive analysis we employ to compare sentencing. Next, we provide an overview of the sentencing laws at the ICTR and in Rwanda, including the factors that were considered during sentencing according to positive law and case law. Finally, we compare the severity of sentences given by the three justice mechanisms.

This analysis demonstrates that sentencing varied across the three levels-ranging from limited time in prison to death sentences and indicating that those convicted of genocide are not necessarily subjected to similar or severe sentences. We likewise find that sentencing at the domestic courts was comparatively more serious than sentencing at the ICTR and the Gacaca courts, suggesting that those deemed most responsible and tried at the ICTR were not subjected to the most severe penalties. This calls into question the consistency of sentencing of genociderelated crimes across the three levels of justice. Finally, we find that sentencing laws and practices for genocide-related crimes in Rwanda became less retributive over time, which we link to highly interconnected principled (e.g., reconciliation) and pragmatic (e.g., overcrowded prisons) reasons.

\section{Three Levels of Justice After Genocide}

People accused of committing crimes during the 1994 genocide and the 1990-1994 civil war in Rwanda were prosecuted, tried, and sentenced at three levels of justice: (i) the International Criminal Tribunal for Rwanda (ICTR); (ii) the domestic courts in Rwanda; and (iii) the local Gacaca courts. ${ }^{4}$ We begin by reviewing each of these court systems.

${ }^{3}$ Academic commentaries have predominantly focused on the ICTR (see, for example, Thierry Cruvelier, Court of Remorse, Inside the International Criminal Tribunal for Rwanda (Wisconsin: University of Wisconsin Press, 2006); Kingsley Moghalu, Rwanda's Genocide, The Politics of Global Justice (New York: Palgrave Macmillan, 2005); or Larissa van den Herik, The Contribution of the Rwanda Tribunal to the Development of International Law, Amsterdam: VU University Amsterdam, 2005). Fewer studies have focused on sentencing at the ICTR (see, for example, Mark Drumbl, Atrocity, Punishment and International Law (New York: Cambridge University Press, 2007); James Meernik, "Proving and Punishing Genocide at the International Criminal Tribunal for Rwanda," International Criminal Law Review 4 (2004), 65-82; or Barbora Hola, Catrien Bijleveld, and Alette Smeulers, "Punishment for Genocide - Exploratory Analysis of ICTR Sentencing," International Criminal Law Review 11, no. 4 (2011), 745-773). Regarding the domestic prosecutions, scholars have mainly focused on Gacaca courts and, within this, on court process (see, among many others, Phil Clark, The Gacaca Courts, Post-Genocide Justice and Reconciliation in Rwanda, Justice without Lawyers (New York: Cambridge University Press, 2010); Anuradha Chakravarty, Investing in Authoritarian Rule, Punishment and Patronage in Rwanda's Gacaca Courts for Genocide Crimes (New York: Cambridge University Press, 2015). Few works have compared all three levels of justice (see Nicola Palmer, Courts in Conflict, Interpreting the Layers of Justice in Post-Genocide Rwanda, New York: Oxford University Press, 2015); Gerald Gahima, Transitional Justice in Rwanda, Accountability for Atrocity (New York: Routledge, 2013); Nicholas Jones, The Courts of Genocide, The Politics and the Rule of Law in Rwanda and Arusha (New York: Routledge, 2009).

${ }^{4}$ It is important to note at the outset that almost all of those tried and convicted by these different justice mechanisms were members of the majority Hutu ethnic group. All people indicted at the ICTR operated in support of the interim government and Hutu extremist policies. Carla del Ponte, who was the Chief Prosecutor between 1999-2003, publicly announced her intention to indict members from the Rwanda Patriotic Front (RPF), who have remained in power following the genocide, but was allegedly prevented from doing so by threats from the Rwandan government to cease any cooperation with the Tribunal. Her successor, Hassan B. Jallow, was not eager to prosecute RPF crimes, as he did not want to alienate the Rwandan government (Filip Reyntjens, Political Government in Post-Genocide Rwanda (New York: Cambridge University Press, 2013), 245). The same holds true within Rwandan domestic courts and Gacaca courts, but data on ethnicity are not available. According to Human Rights Watch, very few members of the 
International Criminal Tribunal for Rwanda

A fraction of those deemed most responsible for the violence were tried at the ICTR. The ICTR was established by the United Nations Security Council on November 8, 1994, ${ }^{5}$ in order to "put an end to [genocide and other systematic, widespread and flagrant violations of international humanitarian law]; [...] bring to justice [those] responsible [...] and [...] contribute to the process of national reconciliation and to the restoration and maintenance of peace." ${ }^{\prime \prime}$ Its jurisdiction was limited to crimes committed in Rwanda and neighboring states between January 1, 1994, and December 31, 1994.

Despite initially supporting the establishment of an international tribunal, Rwanda voted against the Security Council Resolution establishing the ICTR, citing four main reasons: the ICTR's restrictive temporal jurisdiction (i.e., not including events that occurred before 1994); its location outside of Rwanda and related lack of opportunity for Rwanda to influence the functioning of the Tribunal and the selection of its officials; the fact that sentences would be served outside of Rwanda; and, finally, the exclusion of the death penalty as a possible sentence. ${ }^{7}$ Nevertheless, the Tribunal was established in Arusha, Tanzania, and issued its first indictment on November 22, 1995. ${ }^{8}$ The first judgment at the ICTR, and the first conviction for genocide ever issued by an international court, was delivered on September 2, 1998. Jean-Paul Akayesu, a former teacher, school inspector, and mayor of Taba commune, was sentenced to life imprisonment for his participation in killings and acts of sexual violence during the genocide. ${ }^{9}$

In total, 53 judges from various countries served at the ICTR, either in one of the three trial chambers or in the appeals chamber. Judges were selected by the UN General Assembly from lists submitted by the Security Council for a term of four years and were eligible for re-election. ${ }^{10}$ More than three quarters of the ICTR judges were men, and most judges were from Africa (34 percent) and Europe (34 percent).

The ICTR was operational for over twenty years and closed its doors on December 14, 2015, after delivering its last verdict in the Butare case against six defendants, including Pauline Nyiramasuhuko, the former Minister for Family Welfare and the Advancement of Women and the only woman convicted of genocide at the ICTR. ${ }^{11}$ In total, the ICTR indicted 90 individuals for war crimes, crimes against humanity, and/or genocide. ${ }^{12}$ It prosecuted government ministers, regional and local politicians, military leaders, and members of the Interahamwe militia that was active during the genocide. A number of prominent businessmen, clergymen, and representatives of media that spread hate propaganda were also indicted. In total, 73 individuals were tried and received a verdict, ${ }^{13}$ and of these, 14 were acquitted and 59 were convicted. Almost all ICTR

RPF have been tried by the domestic courts. Specifically, fewer than 40 RPF soldiers were tried in domestic courts, and most received comparatively lenient sentences. The Gacaca courts did not try any members of the RPF, as the laws governing the courts omitted reference to war crimes, which made clear that Gacaca was not to try RPF crimes (Human Rights Watch, Rwanda: Justice after Genocide, 20 Years On (New York: Human Rights Watch, 2014), 12). A limited number of individuals were also tried by courts on the basis of universal jurisdiction in several European countries and Canada.

${ }^{5}$ Security Council, Resolution 955 (1994), November 8, 1994, UN Doc. S/RES/ 955 (1994).

${ }^{6}$ Ibid., Preamble.

${ }^{7}$ Gahima, Transitional Justice in Rwanda, 86-87.

${ }^{8}$ Prosecutor versus Clement Kayishema, Ignace Bagilishema, Charles Sikubwabo, Aloys Ndimbati, Vincent Rutaganira, Mikaeli Muhimana, Ryandikayo and Obed Ruzinanda, Indictment, November 22, 1995, ICTR-95-1-1.

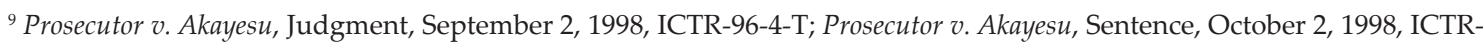
96-4-T.

${ }^{10}$ Art. 12(3) ICTR Statute.

${ }^{11}$ Prosecutor v. Pauline Nyiramasuhuko et al., Appeals Chamber Judgment, December 14, 2015, ICTR-98-42-A.

${ }^{12}$ The MICT and the ICTR websites state that the ICTR "indicted 93 individuals for genocide and other serious violations of international humanitarian law committed in 1994" (see doi: <http://unictr.unmict.org/sites/unictr.org/files/ publications/ictr-key-figures-en.pdf $>$ accessed January 26, 2016). However, this figure is misleading, as it includes the two individuals convicted for contempt of the Tribunal and as one individual, Georges Ruggiu, is listed twice (once under those transferred to serve a sentence and again under those who have already served their sentence).

${ }^{13}$ The remaining 17 defendants had their cases referred to domestic courts in France or Rwanda, had their indictments withdrawn, or never received a final judgment due to death or remaining at large. For a more detailed discussion of those indicted by the ICTR, see Barbora Hola, Alette Smeulers, "ICTR and Rwanda - Facts and Figures," in Elgar 
convicts - 52 out of 59 (88 percent) - were found guilty of genocide, and all were convicted of participation in killings and other offenses against persons. ${ }^{14}$

\section{Domestic Courts in Rwanda}

The domestic courts trying génocidaires in Rwanda were part of a pre-existing court system that had been operational long before the genocide occurred. As the crime of genocide did not exist within Rwanda's criminal code, however, Rwanda enacted a law, known as Organic Law 08/96, to regulate genocide-related prosecutions. ${ }^{15}$ The Organic Law (OL) established Specialized Chambers within the existing domestic courts to try genocide-related crimes. ${ }^{16}$ The Specialized Chambers were given jurisdiction over genocide and crimes against humanity committed since October 1, 1990 (as well as offenses set out in the Penal Code committed "in connection with the events surrounding the genocide and crimes against humanity"). ${ }^{17}$

The OL initially categorized offenders into four categories. Category 1 suspects included planners and organizers of the genocide, those who committed crimes through a position of state authority, notorious murderers who killed with a particular zeal and cruelty, and perpetrators of sexual violence. Category 2 encompassed those who participated in killings, while Category 3 included those who committed other forms of physical violence. Finally, Category 4 suspects included those who participated in crimes against property, although subsequent OLs dealing with genocide-related trials modified the groups falling under each category. Most notably, the OL 16/2004 - which also governed functioning of the Gacaca courts - reduced the number of categories to three. ${ }^{18}$ Category 2 and 3 defendants - those who participated in crimes against persons - were merged into one category (Category 2), and those who committed offenses against property became Category $3 .{ }^{19}$ Punishments were to be commensurate with the crime committed, such that those in Category 1 were to receive harsher punishments than those in Category 2.

Despite the new laws, the Rwandan judicial system was in ruins in the aftermath of the genocide, as it lacked qualified personnel and material infrastructure. ${ }^{20}$ Tens of thousands of genocide suspects were detained in prisons and improvised detention facilities with deplorable conditions and little access to basic hygiene, food, or healthcare. ${ }^{21}$ By 1998, an estimated 120,000 inmates accused of genocide-related crimes were awaiting trial in the overcrowded prisons. ${ }^{22}$ However, the pace of justice was slow. Many nongovernmental organizations lamented the initial

Companion to the International Criminal Tribunal for Rwanda (ICTR), eds. Alette Smeulers and Annemarie de Brouwer, (Glos: Edward Elgar Publishing Ltd., 2016, forthcoming).

${ }^{14}$ In total, nine defendants pleaded guilty and confessed to their crimes. Among the seven individuals who were not found guilty of genocide, four pleaded guilty to charges of crimes against humanity, and three others were convicted of crimes against humanity and war crimes. Note that every individual convicted by the ICTR who was found guilty of war crimes was also found guilty of either genocide or crimes against humanity.

${ }^{15}$ Organic Law (OL) 08/96 on the Organization of Prosecutions for Offences Constituting the Crime of Genocide or Crimes against Humanity Committed since October 1, 1990, adopted on August 30, 1996.

${ }^{16}$ Art. 19 OL 08/96.

${ }^{17}$ Art. 1 OL 08/96.

${ }^{18}$ OL 16/2004 of 19/6/2004 Establishing the Organization, Competence and Functioning of Gacaca Courts Charged with Prosecuting and Trying Perpetrators of the Crime of Genocide and Other Crimes against Humanity, Committed between October 1, 1990 and December 31, 1994, adopted on June 19, 2004.

${ }^{19}$ The OL 08/96 established a precedent for subsequent specific laws, which were issued for the sole purpose of dealing with perpetrators of genocide and crimes against humanity committed between October 1, 1990, and December 31,1994 . This was purposefully a broader jurisdiction than the ICTR in order to try those involved in planning the genocide as well as those involved in attacks after the genocide was declared over in July 1994. The OL 08/96 also included reference to war crimes and the 1949 Geneva Convention on the Protection of Civilians. As noted above, however, war crimes (and especially those allegedly committed by the RPF) were prosecuted in Rwanda only to a very limited extent. The $2004 \mathrm{OL}$, which simultaneously regulated prosecutions of genocide at the domestic courts and at the Gacaca courts, specifically ommitted any reference to war crimes and the Geneva Conventions and consequently excluded trials of RPF crimes.

${ }^{20}$ Cf. Human Rights Watch: Law and Reality. Progress in Judicial Reform in Rwanda (New York: Human Rights Watch, 2008), 12.

${ }^{21}$ Carina Tertsakian, Le Chateau, The Lives of Prisoners in Rwanda (London: Arves Bookes, 2008), 34.

${ }^{22}$ Jones, The Courts of Genocide, 83. 
genocide prosecutions' low standards, including a lack of fundamental fair trial guarantees, corruption, and poor implementation of the right to defense. ${ }^{23}$

Substantial changes were implemented over time, culminating in the 2004 judicial sector reform. The Specialized Chambers that had been created to try genocide-related crimes were abolished in 2000, and the national courts where the chambers had been located were given the authority to try genocide cases. ${ }^{24}$ Specifically, following the 2004 judicial reform, fifteen courts had jurisdiction over genocide-related crimes: the Supreme Court, five High Courts, and nine Higher Instance Courts (as of 2008, the number of Higher Instance Courts - now called Intermediate Courts - had increased to twelve). The decisions of the Higher Instance/Intermediate Courts could be appealed to the High Courts, and under certain circumstances, a request for review could even be lodged at the Supreme Court. Arguably, the standards applied in genocide-related trials improved as a consequence of these reforms. ${ }^{25}$

As official court statistics regarding the initial genocide prosecutions are unavailable, it is difficult to provide an accurate overview of cases tried by the domestic courts. According to Martin Ngoga - the Deputy Prosecutor General of Rwanda at the time-approximately 4,122 individuals were judged by the end of 2001. ${ }^{26}$ Jones reports that an additional 2,335 individuals were tried in 2002 and 2003, ${ }^{27}$ and the United Nations suggests that the Rwandan domestic courts had tried over 10,000 individuals by mid-2006. ${ }^{28}$ In 2005 , the vast majority of genocide-related cases were transferred to the Gacaca courts, however, and the domestic courts only retained jurisdiction over Category 1 cases. ${ }^{29}$ Consequently, as of 2005, the number of the cases tried by the domestic courts dropped to no more than a few hundred.

\section{Gacaca Courts in Rwanda}

Finally, as noted above, cases were also tried in localized Gacaca courts due to the enormity of the caseload of suspected perpetrators. Gacaca courts date back to before Rwanda was colonized. ${ }^{30}$ Gacaca means "grass" in Kinyarwanda, and, as the name implies, traditional hearings took place outside in school yards, empty market places, and other public spaces within Rwandan communities. Respected men presided over these hearings, ${ }^{31}$ which typically dealt with petty crimes and emphasized restitution and community reconciliation. ${ }^{32}$ After the genocide, however, the institution changed significantly. ${ }^{33}$ The new courts - called Inkiko Gacaca (shortened hereinafter

${ }^{23}$ Cf. Mark Drumbl, "Rule of Law amid Lawlessness: Counselling the Accused in Rwanda's Domestic Genocide Trials," 29 Columbia Human Rights Law Review 29 (1998), 550; Human Rights Watch, Rwanda Justice after Genocide 20 Years On, 6; International Crisis Group, Five Years after the Genocide in Rwanda: Justice in Question ( ICG Report Rwanda No. 1, April 7, 1999), 15.

${ }^{24}$ Art. 96 OL 40/2000 Setting Up Gacaca Jurisdictions and Organizing Prosecutions for Offences Constituting the Crime of Genocide or Crimes against Humanity Committed Between October 1, 1990 and December 31, 1994, adopted on January 26, 2001.

${ }^{25}$ Cf. Organic Law 07/2004 Determining the Organization, Functioning and Jurisdiction of Courts in Republic of Rwanda, adopted on February 1, 2004; Jones, The Courts of Genocide, 93-93.

${ }^{26}$ Martin Ngoga, Rwanda 10 Years After the Genocide: Creating Conditions for Justice and Reconciliation. Prosecutor's Colloqium, November 25-27, 2004, accessed March 30, 2016, doi: http://ictr-archive09.library.cornell.edu/ENGLISH/ colloquium04/rwanda.html.

${ }^{27}$ Jones, The Courts of Genocide, 88.

${ }^{28}$ UN Outreach Programme on the Rwanda Genocide and the United Nations, Justice and Reconciliation in Rwanda. Background Note (2012), accessed April 1, 2016, http://www.un.org/en/preventgenocide/rwanda/about/bgjustice. $\underline{\text { shtml }}$.

${ }^{29}$ In 2008, the vast majority of Category 1 cases were transferred to Gacaca courts, and only those deemed the most responsible for the violence were to be tried at domestic courts.

${ }^{30}$ Paul Christoph Bornkamm, Rwanda's Gacaca Courts: Between Retribution and Reparation, (New York: Oxford University Press, 2012), 33.

${ }^{31}$ Phil Clark, The Gacaca Courts, Post-Genocide Justice and Reconciliation in Rwanda: Justice without Lawyers, (New York: Cambridge University Press, 2010), 52.

${ }^{32}$ The Gacaca courts became an officially sanctioned court system for common crimes in the 1940s.

${ }^{33}$ As detailed by the Government, the Gacaca courts had five key objectives. These include the following: (1) identifying the truth about what happened during the genocide; (2) increasing the speed of ongoing trials; (3) fighting a culture 
to Gacaca) - had direct links to the state, which mandated their creation through the same Organic Laws that are noted above.

Per Organic Law, Rwandans elected lay members of their communities to preside over the Gacaca courts as judges known as inyangamugayo, which loosely translates to "trustworthy person" or "person of integrity." Legal training was not required to serve in this capacity. Rather, inyangamugayo had to be 21 years old, could not have prior criminal convictions or have participated in the genocide, and could not have held a position of authority within the government at the time of election. ${ }^{34}$ More than 250,000 men and women were chosen through a series of community elections and were subsequently briefly trained.

Gacaca courts were operational at both the cell (akagari) and sector (umurenge) levels of Rwandan geographic administration. Courts at the cell level were responsible for trying people who were accused of Category 3 crimes (i.e., crimes against property), while courts at the sector level were responsible for Categories 1 (as of 2008) and 2 as well as appeals. In total, there were 9,013 cell courts, 1,545 sector courts, and 1,545 courts of appeal. ${ }^{35}$ Each level of court consisted of a general assembly, a bench of judges, a president, and a coordinating committee. ${ }^{36}$ Community participation was a duty, ${ }^{37}$ and members of the community were expected to attend all trials, which typically occurred on a weekly basis. These Gacaca court trials took place in communities throughout Rwanda until June 2012, when the courts closed. According to the official report of the National Service of Gacaca Courts, the Gacaca courts prosecuted 1,003,227 individuals in 1,958,634 cases during this time. ${ }^{38}$

\section{Methodology}

To assess punishment laws and practices at the ICTR, the Rwandan domestic courts, and the Gacaca courts, we rely upon content analysis of the positive law and case law as well as descriptive analyses of the severity of trial sentences given by the courts. We begin by providing an overview of the laws governing sentencing. This legal analysis draws upon the ICTR Statute, its Rules of Procedure and Evidence, the ICTR case law, and the Rwanda's Organic Laws, which governed both the domestic court trials for genocide as well as the Gacaca court trials.

After briefly analyzing judges' sentencing discretion per law, including whether judges were instructed to take any aggravating and/or mitigating circumstances into account when determining sentences, we turn to a comparison of the sentences given in each of the three court systems. This comparison relies upon descriptive statistics of the sentencing outcomes at each level, and we restrict our analysis to defendants who committed comparable crimes. Given the position of authority and the relative involvement of many of the defendants at the ICTR, they would have all been classified as Category 1 defendants in Rwanda. Therefore, we first provide a comparison of sentences issued by the ICTR, sentences issued by domestic courts in Category 1 cases, and sentences issued by the Gacaca courts in Category 1 cases. As we detail below, the domestic courts also tried Category 2 defendants, ${ }^{39}$ and we thus also compare Category 2 sentences in the domestic courts and in the Gacaca courts.

of impunity; (4) contributing to the national unity and reconciliation process; and, (5) demonstrating the capacity of the Rwandan people to resolve their problems (National Service of Gacaca Jurisdictions, Report on the Activities of the Gacaca Courts, 2012).

${ }^{34}$ Nyseth Brehm, Uggen, and Gasanabo, “Genocide, Justice, and Rwanda's Gacaca Courts," 336.

${ }^{35}$ National Service of Gacaca Jurisdictions, Report on the Activities of the Gacaca Courts, 5.

${ }^{36}$ Lawyers did not participate in the trials, ostensibly to avoid adversarial proceedings, and there were no prosecutorial teams.

${ }^{37}$ Art. 29, OL 16/2004.

${ }^{38}$ Nyseth Brehm, Uggen, and Gasanabo, “Genocide, Justice, and Rwanda's Gacaca Courts," 336.

${ }^{39}$ Again, after the establishment of Gacaca, the OL provided the domestic courts with jurisdiction to deal only with Category 1 cases, and all other cases were to be transferred to Gacaca. Surprisingly, however, the majority of cases we collected at domestic courst decided after 2005 concerned Category 2 defendants. In some instances, judges dismissed the cases on this basis; in other instances, however, they proceeded to rule on the case irrespective of the fact that the case was classifed as Category 2. As such, it is possible that some of these indivdiuals were classifed as Category 1 by the Gacaca and transferred to the ordinary courts, which re-categorized these defendants as Category 2 but proceeded with trials notwithstanding. 
To compare across these three jurisdictions, we focus on trial judgments, meaning we do not take appeal decisions into account. Although the Gacaca data include appeals trials (which constituted 14 percent of all trials held by the courts), it is not possible to match first trials with subsequent appeals with certainty at this point in time. ${ }^{40}$ Thus, we compare first trials across the three jurisdictions in order to achieve the most consistent comparison possible. This accords well with the data collected at the domestic courts, which were mostly trial judgments, and allows us to assess sentences given at the same instance in the judicial process rather than comparing a first sentence in Gacaca against an appeals judgment in the domestic courts or the ICTR. Beyond this, sentencing primarily occurred during the trial phase at each of the three jurisdictions; and as a minority of convicted individuals sought appeals, ${ }^{41}$ taking appeals into account would also necessitate an analysis of the factors that determined a successful appeal, which is beyond the scope of this article.

While a person could only appear once at the ICTR or in the domestic courts, someone could have multiple trials in the Gacaca courts. For instance, if a person was accused of a Category 1 crime and a Category 2 crime, he or she was tried in two separate cases. Similarly, if people were accused of crimes in more than one sector, they were tried in separate cases in each sector. While it is possible to collapse cases across people (results available upon request from the second author, Hollie Nyseth Brehm), Gacaca courts typically did not engage one another but rather made sentencing decisions separately. Because of this, we analyze each person's distinct trial separately rather than combining sentences. For instance, if someone was sentenced to 19 years in one court and 17 years in another, they would appear twice in the dataset, as this most accurately captures sentencing decisions.

\section{Data}

To assess punishments given by the ICTR, we coded and analyzed all trial chamber judgments issued by the ICTR during its mandate. These judgments are published in English on the Tribunal's website. We distinguish between life imprisonment sentences (the maximum) and determinate sentences, which we further divided into 6 categories: 1-5 years, 6-10 years, 11-15 years, 16-20 years, 21-25 years, and more than 26 years. In total, the ICTR trial chambers convicted and handed out sentences to 64 individuals. ${ }^{42}$

The case files used to analyze the practices of domestic courts in Rwanda were collected during fieldwork in Rwanda in 2014 and 2015. As genocide-related cases are archived in physical copies at the respective courts that decided each case, we visited each of these courts and sought access to its archive. ${ }^{43}$ However, the case files at individual courts were often missing ${ }^{44}$ or incomplete. Some,

${ }^{40}$ Many of the individuals who appealed the judgment had multiple trials, and abbreviated Gacaca records did not note which appeal corresponded to which judgment, unfortunately.

${ }^{41}$ At the ICTR, however, over 80 percent of trial judgments (60 cases) were appealed. In less than half of these appeals (29 individuals, or 48.3 percent), the Appeals Chamber confirmed the decision of trial judges, and there was no change in the overall verdict (conviction or acquittal) or sentence length. In 27 instances (45 percent), the Appeals Chamber modified the trial verdict to the benefit of the defendant by either lowering the sentence (22 cases) or acquitting the individual (5 cases). In four cases (6.7 percent), the suspects received a higher penalty upon appeal.

${ }^{42}$ Five individuals (Justin Mugenzi, Prosper Mugiraneza, Augustin Ndindiliyimana, Francois-Xavier Nzuwonemeye and Protais Zigiranyirazo) were, however, subsequently acquitted on appeal. See Prosecutor v Justin Mugenzi and Prosper Mugiraneza, Appeals Chamber Judgment, February 4, 2013, ICTR-99-50-A; Prosecutor v. Augustin Ndindiliyimana, Francois-Xavier Nzuwonemeye and Innocent Sagahutu, Appeals Chamber Judgment, February 11, 2014, ICTR-00-56-A; Prosecutor v. Protais Zigiranyirazo, Appeals Chamber Judgment, November 16, 2009, ICTR-01-73-A.

${ }^{43}$ In order to secure maximal comparability of the data, the fieldwork initially aimed to collect only cases decided by Rwandan domestic courts after the establishment of Gacaca in 2005, as sentencing at both Gacaca and domestic courts was governed by the same OLs. We obtained access to cases involving 353 of the individuals tried between 2005 and 2014.

${ }^{44}$ According to the Supreme Court's annual reports, the domestic courts decided cases involving 567 individuals in the period between 2005 and 2012. (See The Republic of Rwanda: Supreme Court: RAPORO, Y'IBIKORWA BY'URWEGO RW'UBUCAMANZA, 2004-2011, 2011-2012, 2012-2013, on file with authors.) The difference in the reported and collected cases decided by domestic courts as of 2005 could be ascribed to over-reporting in the official statistics and/ or weak archiving practices. Thus, given the difficulty in obtaining complete records, we decided to modify our strategy and began collecting all genocide-related cases made available to us, irrespective of the year of the verdict. 
for example, contained only an appeal or a review judgment without a first instance decision or only the trial judgment without any subsequent decisions. We have, nonetheless, collected and coded all judgments that were made available to us. This means that we seldom gained access to all documents mapping the complete trajectory of all individuals through the justice system (i.e., indictment, trial judgment, appeals judgment, and eventual review), though the majority of the documents collected were trial judgments. In total, we collected and coded cases concerning 651 individuals tried between 1995 and 2014. In addition, we coded all judgments published by Avocats Sans Frontiéres concerning the cases of 528 individuals decided between 1997 and 2005. We have thus collected case files concerning 1,179 individuals tried at domestic courts. Out of these, we have analyzed 871 individual verdicts issued by first instance courts. For the remaining 308 individuals, we collected only the appeals or review judgments; they are consequently excluded from our analysis in order to facilitate comparison with Gacaca data.

With respect to Gacaca judgments, we draw upon official records that were kept by the National Service of Gacaca Jurisdictions. This unit was the administrative arm of the Gacaca courts, and they compiled records from all trials, including the complete judgment for each case. Millions of these records were kept in official notebooks, which are currently being archived in Kigali. This process will take years, though Gacaca employees also transferred abbreviated forms of court records into thousands of Excel files that contain information about all individuals accused of participating in the genocide, including but not limited to whether they were found guilty, the punishment, and the category of crime. We obtained the Excel files for each administrative region within Rwanda. These abbreviated court records from 10,558 courts ${ }^{45}$ were then compiled into a single database of Gacaca files. For our analysis, this includes 63,828 cases with a guilty verdict in Category 1 and 254,806 cases with a guilty verdict in Category $2 .{ }^{46}$ Note that we do not include those convicted of crimes against property (Category 3 as of 2004 according to the OL 16/2004 as amended), as these crimes differ substantially from the crimes that were to be tried at the ICTR and in the domestic courts.

The data on the Rwandan domestic trials and on the Rwandan Gacaca court trials are unique, as we are part of the only research team that has gained access to and compiled these data. ${ }^{47}$ That said, several caveats must be discussed prior to our analysis. First, some have suggested that the government of Rwanda has a particular interest in controlling or manipulating information about genocide perpetrators, which could influence data on both the domestic courts and the Gacaca courts. We have seen no evidence to suggest that any of the data we analyzed were subject to such manipulation; we obtained these data in a disorganized state and assembled our datasets from scratch. Nonetheless, like other court systems, court systems in Rwanda-and, specifically, the Gacaca courts - were also subject to corruption. ${ }^{48}$ For example, communities sometimes discovered that the judges they had elected to preside over Gacaca court trials had participated in the violence, and revenge or petty arguments may have motivated some of the cases. ${ }^{49}$ We do not doubt that these and other concerns are valid, but they are also unlikely to compromise the large-scale analysis of sentences.

Finally, less than 0.5 percent of Gacaca cases resulting in a guilty verdict did not include the sentence or included a nonsensical sentence and are thus excluded. Missing data for the domestic courts are of larger concern. Again, as opposed to the ICTR and the Gacaca courts, there is no centralized database of genocide-related cases decided by the domestic courts. Compared to official

\footnotetext{
${ }^{45}$ This number excludes appeals courts, which are not considered in this analysis.

${ }^{46}$ As explained above, the data from the Gacaca courts are person-cases. Thus, if four people were involved in a crime, they would each be listed once for that crime, totaling four cases even if those cases were tried concurrently. Additionally, if one person committed two different crimes, he or she appears twice in the database. As the courts did not take other crimes committed into account when deciding sentences in discrete cases, we would keep both cases in this example in the database in order to most accurately examine the sentences that were given across all cases.

${ }^{47}$ To be clear, some of the Gacaca court judgments were published online and have been used to assess participation in the genocide. However, only a fraction of the judgments were made available in this manner.

${ }^{48}$ Coel Kirkby, "Rwanda's Gacaca Courts: A Preliminary Critique," Journal of African Law 50, no. 2 (2006), 111.

${ }^{49}$ Phil Clark, The Gacaca Courts, 119.
} 
statistics and numbers reported by scholars described above, the data collected from the Rwandan domestic courts present a limited picture of the proceedings, especially for pre-2005 prosecutions. However, given the state of judicial archives in Rwanda, it will arguably never be possible to conduct a systematic and conclusive empirical review of all genocide-related cases decided by the domestic courts. To our knowledge, our database is the most comprehensive dataset on genociderelated prosecutions ever compiled and analyzed, though these limitations must be kept in mind when examining the data.

\section{Sentencing Laws at the ICTR and in Rwanda}

Before assessing these data, we begin with an analysis of the sentencing laws. The two most important legal documents governing the functioning of the ICTR were its Statute, which was appended to UNSC Resolution 955, and the ICTR Rules of Procedure and Evidence (RPE), which was adopted on June 29, 1995, and regularly amended afterward. ${ }^{50}$ The Statute and the RPE, however, contain only very basic guidelines regarding sentencing. Article 23 of the ICTR Statute limits available sentences to imprisonment. When determining the penalty, judges were instructed to take into account factors such as the gravity of the offense and the individual circumstances of the convicted person. The Statute does not define what the assessment of gravity entails or which individual circumstances could be considered relevant, however. The Statute also instructed judges to consider the general practice regarding prison sentences in the courts of Rwanda, ${ }^{51}$ though no sentencing tariff is provided for crimes under the Tribunal's jurisdiction.

The RPE likewise provides limited clarification regarding how sentences should be determined. Specifically, Rule 101 limits the range of applicable sentences, with a maximum sentence of life imprisonment. Judges were also instructed to take into account any aggravating and/or mitigating circumstances when determining sentences. However, no list of aggravating and mitigating factors is provided. Only two potential mitigating factors - "superior orders" 52 and "substantial cooperation with the Prosecutor" 53 - are explicitly mentioned. Consequently, the ICTR judges had much sentencing discretion.

Despite this broad maneuvering space for sentence determination, judges developed a relatively consistent approach to sentencing in case law over time. In fact, a common set of general sentencing principles and individual sentencing factors was emphasised by the ICTR judges across all cases. ${ }^{54}$ The starting point of sentence determination and the litmus test for sentence severity was, according to the ICTR judges, the gravity of the offence. ${ }^{55}$ In this respect, the principles of proportionality, totality, and gradation were the governing criteria: a penalty was to reflect the totality of the crimes committed by a person and be proportionate to the gravity of his or her crimes while taking into account his or her position in the overall conflict and role in the particular crimes. For the purposes of sentencing, gravity was primarily determined in concreto by examining the particular circumstances of the case. ${ }^{56}$ In most cases, the concept of gravity was interpreted as

${ }^{50}$ The last amendment listed in the Rules was adopted on May 13, 2015. See ICTR Rules of Procedure and Evidence; Adopted on June 29, 1995, as amended, accessed June 19, 2016, doi: http://unictr.unmict.org/sites/unictr.org/files/legallibrary/150513-rpe-en-fr.pdf.

${ }^{51}$ Art. 23(1) ICTR Statute. The ICTR judges ruled, however, that national practices should serve solely as a point of reference and should not be treated as binding. Cf. Prosecutor v. Nahimana, Barayagwiza, Ngeze, Appeals Chamber Judgment, November 28, 2007, ICTR-99-52, para. 1063. As discussed below, however, the sentencing approach of the ICTR and within Rwanda seemed to be based on comparable tenets, which might be the result of the ICTR judges implicitly taking inspiration from Rwandan laws.

${ }^{52}$ Art. 6(4) ICTR Statute.

${ }^{53}$ Rule 101(B)(i) RPE.

${ }^{54}$ Cf. Barbora Hola, International Sentencing - “Game of Russian Roulette” or Consistent Practice? (Oisterwijk: BOXPress, 2012), 209; Silvia D'Ascoli, Sentencing in International Criminal Law, The UN Ad Hoc Tribunals and Future Perspectives for the ICC, (Oxford: Hart Publishing, 2011).

${ }^{55}$ Cf. Prosecutor v. Akayesu, Appeals Chamber Judgment, November 23, 2001, ICTR-96-4-A, para. 413; Prosecutor v. Rutaganda, Appeals Chamber Judgment, May 26, 2006, ICTR-96-3, para. 591.

${ }^{56}$ Over time, the ICTR judges seem to have rejected the notion of abstract hierarchy between individual categories of international crimes. In early jurisprudence, genocide was denoted as the crime of crimes, and judges argued that for the purposes of sentencing, genocide as a category of international crime was considered more serious than 
encompassing two aspects: (i) the magnitude of harm caused by the offender as represented for example by the scale of the crime, the number of victims, and the extent of victims' suffering; and (ii) the form and degree of the accused's participation in the crime (in other words, the offender's culpability)..$^{57}$

After evaluating the gravity of crimes, the ICTR judges further individualized the sentence by assessing aggravating and mitigating circumstances. Only those circumstances directly related to the charged offences and to the offenders when they committed the offence were accepted in aggravation..$^{58}$ Conversely, mitigating factors did not need to relate directly to the offences, and judges typically discussed the offender's personal circumstances, including but not limited to his or her character, family circumstances, or behavior prior to the genocide. ${ }^{59}$ Over the years, the Tribunal accepted a wide range of factors in aggravation/mitigation of a sentence. ${ }^{60}$ The most common aggravating factor cited by ICTR judges was the abuse of a position of authority, leadership, influence, or trust, ${ }^{61}$ while assistance to victims was cited most frequently in mitigation. ${ }^{62}$

As most of the crimes tried at the ICTR were very serious and often entailed the deaths of hundreds or thousands of victims - and as all would have likely resulted in the severest sentences in domestic jurisdictions - the ICTR judges seemed to differentiate between serious criminal acts and even more serious criminal acts. This differentiation was primarily conducted by applying the principle of gradation, which involved the evaluation of the defendants' culpability as manifested by their position in the state hierarchy and the role that they played in particular crimes. The severest sentence of life imprisonment was consequently reserved for the most serious offenders, ${ }^{63}$ such as those who planned, led, or ordered atrocities and those who committed crimes with particular zeal or sadism. Accordingly, judges often reiterated that offenders receiving the most severe sentences previously held senior positions of authority, such as ministers in the government. ${ }^{64}$

As opposed to the almost unfettered sentencing discretion at the ICTR, the Rwandan OLs limited the sentencing discretion of judges at the domestic courts and inyangamugayo at the Gacaca courts to a considerable extent. As noted above, as of 2000, the OLs uniformly regulated genociderelated prosecutions at both the Rwandan domestic courts and the Gacaca courts. The laws contain fixed mandatory sentences and narrow sentencing tariffs with a very limited margin of appreciation provided for judges to take into account the particularities of each case.

The first genocide prosecution law, the OL 08/96, introduced the categorization of genocide suspects and gradation in sentence severity depending on the defendant's category. ${ }^{65}$ Per this

war crimes. (Cf. Prosecutor v. Serushago, Judgment, February 5, 1999, ICTR-98-39, para.13; Prosecutor v. Rutaganda, Judgment, December 6, 1999, ICTR-96-3, para. 451; Prosecutor v. Musema, Judgment, January 27, 2000, ICTR-96-13, para. 981; Prosecutor v. Kambanda, Judgment, September 4, 1998, ICTR-97-23, para. 14). Over time, however, the judges emphasized that there is no hierarchy among individual categories of international crimes and that all crimes under their jurisdiction represented very serious violations of international humanitarian law. Cf. Prosecutor v. Renzaho, Judgment, July 14, 2009, ICTR-97-31-T, para. 817; Prosecutor v. Elizaphan \& Gérard Ntakirutimana, Judgment, February 21, 2003, ICTR-96-10 \& ICTR-96-17, para. 776; Prosecutor v. Rukundo, Appeals Chamber Judgment, October 20, 2010, ICTR-2001-70, para. 260.

${ }^{57}$ For a more elaborate discussion of the concept of gravity, see Hola, International Sentencing, 47-56.

${ }^{58}$ For a short list of accepted aggravating factors, see, e.g., Prosecutor $v$. Nyiramasuhuko et al., Judgment, June 24, 2011, ICTR-98-42-T, para. 6193, 6194.

${ }^{59}$ Prosecutor v. Ndindabahizi, Judgment, July 15, 2004, ICTR-01-71, para. 502.

${ }^{60}$ For a complete list, see Hola, International Sentencing, 77-82.

${ }^{61}$ Ibid., at 165.

${ }^{62}$ It should not be assumed, however, that assistance to victims was always accepted in mitigation. Indeed, judges often rejected defendants' requests for sentence mitigation on these grounds. In particular, selective assistance to victims did not necessarily result in sentence mitigation. In some ICTR judgments, the Trial Chambers refused to accept this factor in mitigation or have even indicated that it could have aggravated a sentence. Prosecutor v. Bikindi, Judgment, December 2, 2008, ICTR-01-72, para. 457; Prosecutor v. Muvunyi, Appeals Chamber Judgment, September 12, 2006, ICTR-2000-55A, para. 540 .

${ }^{63}$ Prosecutor v. Nahimana, Barayagwiza, Ngeze, Judgment, December 3, 2003, ICTR-99-52, para. 1097.

${ }^{64}$ Prosecutor v. Setako, Judgment, February 25, 2010, ICTR-04-81, para. 500.

${ }^{65}$ OL 08/96 on the Organization of Prosecutions for Offences Constituting the Crime of Cenocide or Crimes Against 
law, Category 1 defendants (those seen as particularly responsible or cruel) were liable to the death penalty with no possibility of sentence reduction or mitigation. ${ }^{66}$ The mandatory sentence for Category 2 offenders (those who participated in killings) was life imprisonment. Category 3 suspects (including those who participated in acts causing personal injuries short of death) were to be given penalties stipulated for similar offences by the Penal Code of Rwanda. Finally, Category 4 suspects (those who committed offenses against property) were not to be subjected to incarceration and were instead to pay reparations. OL 08/96 also stipulated a possibility for Category 2 and 3 defendants to confess and plead guilty, which, if accepted by the court, would lead to a significant reduction in their sentence. For example, a Category 2 defendant who pled guilty could be given either 7 to 11 years (if the guilty plea took place prior to prosecution) ${ }^{67}$ or 12 to 15 years (if the defendant confessed during the trial, illustrating that time of confession was also to be taken into account). ${ }^{68}$

This first genocide prosecution law set the scene for the subsequent developments in sentencing structures for convicted génocidaires in Rwanda. In 2000, the most important changes were introduced by the OL creating the Gacaca courts. ${ }^{69}$ Due to the new court system, a majority of genocide cases (all cases concerning Category 2, 3, and 4 defendants) were to be transferred to Gacaca. ${ }^{70}$ The OL on Gacaca was subsequently amended several times, ${ }^{71}$ most substantially in $2004^{72}, 2007^{73}$ and $2008 .^{74}$ In essence, however, the strict regulation of sentencing remained; there were mandatory sentences depending on offender categorization, and very limited discretion was provided to the judges.

As noted above, the subsequent OLs modified the groups falling under each category and, as of 2004, re-categorized genocide suspects into three categories by combing Categories 2 and 3. In addition, the severity of the mandatory sentences was progressively reduced in the years following OL 08/96. Category 1 defendants also became eligible for sentence reduction if they confessed, and the traditional sanction of incarceration was offset by alternative sanctioning mechanisms such as community service (Travail d'Intérêt Général, known as TIG) or suspended sentences. As of 2000, Category 2 defendants who were accused of killing and confessed and Category 3 defendants convicted of injuring a person were to serve only half of the pronounced sentence in prison, and the rest was to be commuted to community service.$^{75}$ Rwanda also formally abolished the death penalty in 2007 and substituted it with a sentence of life imprisonment or life imprisonment with special

Humanity Committed since October 1, 1990, adopted on August 30, 1996.

${ }^{66}$ Ibid., Art. 14.

${ }^{67}$ Ibid., Art. 15.

${ }^{68}$ Ibid., Art. 16. The Rwandan government introduced the notion of confession and the possibility of a significant reduction in sentences tied to confession in order to motivate the tens of thousands of defendants who were detained in overcrowded prisons and ad-hoc detention centers to come forward, confess their crimes, and assist the government in easing prison overcrowding and reducing the backlog of genocide-related cases.

${ }^{69}$ OL 40/2000 Setting Up Gacaca Jurisdictions and Organizing Prosecutions for Offences Constituting the Crime of Genocide or Crimes against Humanity Committed Between October 1, 1990 and December 31, 1994, adopted on January 26, 2001.

${ }^{70}$ Again, in 2008, the majority of Category 1 defendants were transferred to Gacaca jurisdictions, leaving the domestic courts to try only planners and organizers as well as leaders at the national and prefecture (region) level.

${ }^{71}$ For example, OL 33/2001, which was adopted in 2001, modified OL 40/2000.

${ }^{72}$ OL 16/2004 of 19/6/2004 Establishing the Organization, Competence and Functioning of Gacaca Courts Charged with Prosecuting and Trying Perpetrators of the Crime of Genocide and Other Crimes against Humanity, Committed Between October 1, 1990 and December 31, 1994, adopted on June 19, 2004.

${ }^{73}$ OL 10/2007 of 01/03/2007 Modifying and Complementing Organic Law 16/2004 of 19/6/2004 Establishing the Organization, Competence and Functioning of Gacaca Courts Charged with Prosecuting and Trying Perpetrators of the Crime of Genocide and Other Crimes against Humanity, Committed between October 1, 1990 and December 31, 1994 as Modified and Complemented to Date, adopted on March 1, 2007.

${ }^{74}$ OL 13/2008 Modifying and Complementing OL 16/2004 of 19/6/2004 Establishing the Organization, Competence and Functioning of Gacaca Courts Charged with Prosecuting and Trying Perpetrators of the Crime of Genocide and Other Crimes against Humanity, Committed between October 1, 1990 and December 31, 1994 as Modified and Complemented to Date, adopted on May 19, 2008.

${ }^{75}$ Cf. Art. 69, 70 OL 40/2000; or 73,78 , and 80 of the OL 16/2004, as amended. 
provisions. ${ }^{76}$ Effectively, however, the death penalty had already been abolished in 1998. While the death penalty was stipulated in the OL and regularly given as a sentence in the Specialized Chambers, as we further address below, there is only record of 22 individuals who were executed in April 1998.

These changes, including the progressive introduction of less retributive sanctions, could be explained by the fact that the Rwandan government also emphasized other non-retributive goals of transitional justice with the introduction of the Gacaca courts. These goals included but are not limited to the involvement of the broader population in dealing with the past, truth finding, reconciliation, societal reconstruction, and reintegration of defendants. In addition to these principled reasons, highly interconnected practical considerations such as a backlog of cases at the Specialized Chambers, overcrowded prisons, or having a large proportion of the adult Hutu male population in detention could arguably also explain the progressive changes in punishment structures.

Table 1 outlines the sentencing structures for Rwandan domestic courts and Gacaca courts as amended and modified in 2008 after the adoption of OL 13/2008. ${ }^{77}$ The rows indicate the category of a defendant according to the OL, and the columns are further divided based on sentences stipulated (i) for adult defendants who did not confess (Column 1); (ii) for adult defendants who confessed (Column 2); and (iii) for minors at the time of genocide, again depending on whether they confessed (Column 3). The categorization of defendants determined not only the sentence severity but also whether a case was handled by the Gacaca courts (Cat. 1 C, D, and E, Cat. 2, and Cat. 3) or tried at ordinary courts (Cat. $1 \mathrm{~A}$ and B).

Similar to the first OL on genocide-related prosecutions, suspected génocidaires were placed into categories that corresponded to mandatory sentences or sentence ranges. The categorization depended on the defendant's role in the crime, whether the defendant held a position of authority, and the type of offense. Category 1 defendants (broadly those organizing atrocities, those in positions of authority, and perpetrators of sexual violence) were to receive the most severe sentences. The remaining Category 2 and 3 offenders were divided depending on whether the crimes they participated in were targeting people (Category 2 ) or property (Category 3 ), with a clear decrease in sentence severity depending on the type of crime committed. Each category also includes accomplices, who were defined as individuals who had provided any form of assistance to commit offenses specified in each category. ${ }^{78}$ The OL leaves the individual terms further undefined and thus provides those implementing the laws with relatively broad discretion on whom to classify as an organizer and on the meaning of terms such as "notorious murderer." Indeed, according to OL 16/2004, the Gacaca courts were competent to categorize offenders and to compile lists of offenders for each Category. ${ }^{79}$ As the categorization of an offender was meant to be tied to sentence severity, this discretion suggests that the legal straightjacket imposed by the OLs was not as tight as it might have originally seemed, at least when it comes to sentencing. Judges and inyangamugayo were able to circumvent limitations on their sentencing discretion by exercising greater discretion in the offender categorization stage or by re-categorizing cases.

\footnotetext{
${ }^{76}$ OL 31/2007 Relating to the Abolition of the Death Penalty. In the cases where the death penalty had been pronounced before the adoption of OL 31/2007, and in all legal texts containing the death penalty as a punishment, life imprisonment or life imprisonment with special provisions was substituted for the death penalty (Art. 3, Art. 6). Given that crimes against humanity and genocide are subject to life imprisonment with special provisions (Art. 5, para. 3), those sentenced the death penalty likely had their sentence changed to life imprisonment with special provisions.

77OL 13/2008 Modifying and Complementing OL 16/2004 of 19/6/2004 Establishing the Organization, Competence and Functioning of Gacaca Courts Charged with Prosecuting and Trying Perpetrators of the Crime of Genocide and Other Crimes against Humanity, Committed between October 1, 1990 and December 31, 1994 as Modified and Complemented to Date, adopted on May 19, 2008.

${ }^{78}$ Art. 53 OL 16/2004.

${ }^{79}$ Art. 34 OL 16/2004, Ibid. The list of Category 1 suspects was published by the Chief Prosecutor of the Supreme Court periodically since OL 08/96. Initially, the information regarding who to put on the list of suspects was forwarded by local administrative and judicial authorities (see Alison Des Forges, Leave None to Tell the Story, Genocide in Rwanda (New York: Human Rights Watch, Second Edition, 1998), 751). After the Gacaca courts began, the information was forwarded by the Gacaca courts.
} 
Table 1. Offender Categorization and Sentencing Structure in the Rwandan OL16/2004 (as Amended by OL 10/2007 and OL 13/2008, with numbers indicating stipulated sentences in years in prison).

\begin{tabular}{|c|c|c|c|c|c|c|c|}
\hline \multirow{3}{*}{\multicolumn{2}{|c|}{ Offender Categorization }} & \multirow{3}{*}{$\begin{array}{l}\text { NO } \\
\text { CONFESSION }\end{array}$} & \multicolumn{2}{|c|}{ CONFESSION* } & \multicolumn{3}{|c|}{$\begin{array}{l}\text { MINOR } \\
\text { (at the time of crimes) }\end{array}$} \\
\hline & & & \multirow{2}{*}{\begin{tabular}{|l} 
Before \\
Being \\
Listed ${ }^{* *}$
\end{tabular}} & \multirow{2}{*}{$\begin{array}{l}\text { After } \\
\text { Being } \\
\text { Listed }\end{array}$} & \multirow{2}{*}{$\begin{array}{l}\text { No } \\
\text { Confession }\end{array}$} & \multicolumn{2}{|c|}{ Confession } \\
\hline & & & & & & $\begin{array}{l}\text { Before } \\
\text { Being } \\
\text { Listed }\end{array}$ & $\begin{array}{l}\text { After } \\
\text { Being } \\
\text { Listed }\end{array}$ \\
\hline CAT. 1 & $\begin{array}{l}\text { A) Planners/organizers } \\
\text { B) National/prefectural } \\
\text { leaders } \\
\text { C) Inciters/supervisors/ } \\
\text { ringleaders } \\
\text { D) Sub-prefectural/ } \\
\text { commune leaders } \\
\text { E) Perpetrators of } \\
\text { sexual violence }\end{array}$ & $\begin{array}{l}\text { Life in prison } \\
\text { with special } \\
\text { provisions }\end{array}$ & $20-24$ & $25-30$ & $10-20$ & $6.5-7.5$ & $8-9$ \\
\hline \multirow[t]{3}{*}{ CAT. 2} & $\begin{array}{l}\text { A) Notorious } \\
\text { murderers } \\
\text { B) Torture } \\
\text { C) Dehumanizing dead } \\
\text { body }\end{array}$ & $\begin{array}{l}30 \text { years in } \\
\text { prison or life }\end{array}$ & $20-25$ & $25-29$ & $10-15$ & 6-7 & $6.5-7.5$ \\
\hline & $\begin{array}{l}\text { D) Killers } \\
\text { E) Injury with intent } \\
\text { to kill }\end{array}$ & $25-30$ & $7-12$ & $12-15$ & $4.5-5.5$ & $2.5-3.5$ & 4-5 \\
\hline & $\begin{array}{l}\text { F) Injury with no intent } \\
\text { to kill }\end{array}$ & $5-7$ & $1-3$ & $3-5$ & $2.5-3.5$ & $0.5-1.5$ & $1.5-2.5$ \\
\hline CAT. 3 & A) Property offences & Reparation ${ }^{* * *}$ & \multicolumn{2}{|c|}{ Reparation } & Reparation & & \\
\hline
\end{tabular}

* To have a confession accepted, a defendant had to provide a detailed account of the crime that included eventual witnesses, victims, and the damage caused; identify his or her co-perpetrators; and apologize to the victims or their families. If the confession did not adhere to these stringent requirements, it could be rejected. The defendant would then be sentenced as if he or she did not confess (see Article 54 of OL 16/2004). In addition, the moment of confession—specifically whether a defendant confessed before being put on the list of suspects or only afterward - mattered for sentence severity.

** According to the OL 16/2004 (Article 34), the Gacaca courts at the cell level were responsible for compiling and categorizing lists of suspects responsible for crimes committed within their cells. Those put on Category 3 lists were then tried by the same cell level Gacaca court. Lists of Category 2 suspects were to be forwarded to sector level Gacaca courts, and lists of Category 1 suspect were to be forwarded to the Public Prosecution.

*** Note that there were numerous types of sanctions linked to Category 3 offenses, though we do not include these sanctionswhich mostly involved paying fines to victims and/or their families-here because Category 3 is not part of our analysis.

Beyond the offender categorization, the severity of mandatory sentences stipulated in the OL was also largely dependent on two types of mitigating excuses ${ }^{80}$ that could have led to a considerable sentence reduction: (i) confession and guilty plea; ${ }^{81}$ and (ii) minor age of a defendant

${ }^{80}$ Sam Rugege and Aime M. Karimunda, "Domestic Prosecution of International Crimes: The Case of Rwanda," in Africa and the International Criminal Court, ed. Gerhard Werle et al. (The Hague: International Criminal Justice Series 1, T.M.C. Asser Press, 2014), 90.

${ }^{81}$ Art. 72, 73 OL 16/2004 as amended. 
at the time of the genocide (offenders between 14 and 18 years ${ }^{82}$ old were considered minors).$^{83}$ Judges in domestic courts and in Gacaca courts were also able to adjust a sentence within the predetermined ranges if mitigating or aggravating circumstances were present. ${ }^{84}$ The OL does not provide a list of relevant mitigating circumstances and left it to the discretion of judges to accept relevant mitigating circumstances, however. ${ }^{85}$ In contrast, the OL explicitly stipulates the following factors as aggravating: (i) a position of authority at thelevel of a cell or a sector; ${ }^{86}$ and (ii) the combination of multiple offenses falling within the same category committed by a defendant. ${ }^{87}$ In such cases, judges were directed to hand out the most severe penalty envisaged within the defendant's category. ${ }^{88}$

Overall, this overview demonstrates that at the ICTR and in Rwanda, it was the culpability of the offender that was to primarily influence sentence severity. Culpability was to be assessed based on the position of authority (those exercising state authority were to be considered the most culpable), the particular role in the offenses committed (organizers, planners, and leaders of the massacres were to be considered the most culpable), and the manner of execution (those who committed crimes with a particular cruelty and zeal were to be considered most culpable). The type of underlying offence and its gravity arguably was to influence the sentence severity only secondarily. In addition, a significant mitigating factor for genocide-related sentences, especially in Rwandan law, was a confession. This was justified by the fact that punishment of genocide was meant not only to condemn the crimes and those responsible but also to fulfill other societal functions such as truth finding or promoting reconciliation.

\section{Sentencing Practices/Outcomes at the ICTR and in Rwanda}

In order to compare sentencing of genocide, it is not sufficient to analyze the law itself. Rather, it is also vital to understand how the laws were implemented in practice by judges and inyangamugayo. Put another way, the laws we have reviewed do not necessarily dictate practice, and judges and inyangamugayo-especially those in more decentralized courts-may have departed from these sentencing guidelines. Consequently, this section contrasts the severity of sentences issued at the ICTR, the domestic courts, and the Gacaca courts. We first focus on the most serious casesCategory 1 trials in domestic courts, Category 1 trials in the Gacaca courts, and those tried the ICTR. We then compare Category 2 trials at the domestic courts and at Gacaca.

\section{ICTR and Category 1 Offenders at Domestic Courts and Gacaca Courts}

Table 2 provides an overview of case outcomes in each jurisdiction based on the data the described above. As seen in the table, the conviction rates at the ICTR, domestic Rwandan courts, and Rwandan Gacaca courts were relatively similar. Approximately 71 percent of initial ICTR trials ended with a guilty verdict, as compared to 76 percent of domestic court trials and 75 percent of Gacaca trials of Category 1 suspects. The remaining cases were acquitted or, in the case of the ICTR and the domestic courts, dismissed, transferred, or never held. Gacaca trials were unique in that defendants were tried in absence if they were unable to be present; in these cases, judges were able to take community testimony into account in their judgments. In the subsequent analysis, we examine only those who were convicted, and we present our findings in percentages in order to facilitate comparison across jurisdictions.

\footnotetext{
${ }^{82}$ Those who were less than 14 at the time of the genocide were not to be prosecuted but were to be sent to training camps instead (Organic Law 13/2008).

${ }^{83}$ Art. 78 OL 16/2004 as amended.

${ }^{84}$ Art. 81 OL $16 / 2004$ as amended.

${ }^{85}$ Rugege and Karimunda, Domestic Prosecution of International Crimes, 90-91. The authors also provide examples of situations where judges accepted remorse or cooperation with the court as mitigating circumstances. In addition, the Manuel Explicatif sur la loi organique portant creation des jurisdictions Gacaca also lists possible mitigating circumstances for Gacaca judges, such as vulnerability of a defendant, undue influence, or saving lives.

${ }^{86}$ Art. 52 OL 16/2004 as amended.

${ }^{87}$ Art. 77 OL 16/2004 as amended.

${ }^{88}$ In contrast to the ICTR, where incarceration was the only possible sentence, the OLs in Rwanda also stipulate an additional penalty, which is the withdrawal of civic rights. The extent and duration of withdrawal was to depend on the category of the offender. Art. 76 OL 16/2004 as amended.
} 
Table 2. Convictions and Acquittals at the ICTR and in Rwandan Domestic and Gacaca Court Trials.

\begin{tabular}{lcccccc}
\hline & \multicolumn{2}{c}{ Convicted } & \multicolumn{2}{c}{ Acquitted } & \multicolumn{2}{c}{ Dismissed/Transferred/At Large } \\
\hline & $\%$ & Number & $\%$ & Number & $\%$ & Number \\
\hline ICTR & 71.1 & 64 & 10.0 & 9 & 18.9 & 17 \\
Domestic Courts* & 76.0 & 662 & 15.8 & 138 & 8.2 & 71 \\
Gacaca Category 1 & 75.4 & 63,828 & 24.6 & 20,757 & NA/Unknown & NA/Unknown \\
\hline
\end{tabular}

* While the domestic courts were meant to try Category 1 offenders, Category 2 and 3 offenders were also tried in these courts. In this table, we include all trials with first instance verdicts. However, in Table 2, we restrict the data presented to Category 1 trials and also analyze Category 2 trials below.

As seen in Table 3, despite the relative parity in the conviction rates across jurisdictions, sentences varied widely. The median sentence at the ICTR was 25 years, followed by 14 years in the domestic courts' Category 1 trials and 19 years in the Gacaca courts' Category 1 trials. The fact that the ICTR's median sentence length is the highest is to be expected, as this court tried those who played comparatively larger roles in the violence. That said, the Gacaca courts' median sentence is 5 years longer than the median sentence in the domestic courts. While this suggests that determinate sentencing at the Gacaca courts was harsher than sentencing at the domestic courts, this number must be analyzed alongside the sentences for life in prison and the death penalty. As with determinate sentences, the ICTR had the highest percentage of life sentences: 42.2 percent of all cases tried at the ICTR resulted in a life sentence. This is contrasted against 12.2 percent in domestic courts and 16.5 percent in Gacaca, though an additional 66.0 percent of cases for Category 1 offenders in the domestic courts resulted in the death penalty. To be clear, the vast majority of these cases were eventually converted into life sentences, though we report them as the death penalty in Table 3 to comport with our focus on initial verdicts.

Table 3. General Sentencing Outcomes in the ICTR and in Rwanda*

\begin{tabular}{ccccccc}
\hline & $\begin{array}{c}\text { Median } \\
\text { Sentence }\end{array}$ & Range & $\begin{array}{c}\text { Determinate } \\
\text { Sentence (DS) }\end{array}$ & $\begin{array}{c}\text { Life } \\
\text { Sentence }\end{array}$ & $\begin{array}{c}\text { Death } \\
\text { Penalty }\end{array}$ & TIG** \\
\hline Years & Years & $\%$ & $\%$ & $\%$ & $\%$ \\
\hline ICTR & 25 & 6 to 35 & 57.8 & 42.2 & NA & NA \\
Domestic Category 1 & 14 & 2 to 30 & 21.8 & 12.2 & 66.0 & - \\
Gacaca Category 1 & 19 & 1 to 30 & 83.5 & 16.5 & NA & 13.1 \\
\hline
\end{tabular}

* We have data on 147 Category 1 trials from the domestic courts, which are shown here. The remaining trials were Category 2 trials, which are not included here but which we further explain below.

** Judges and inyangamugayo in both domestic courts and Gacaca courts were instructed according to Art. 73 OL16/2004 to convert half of a pronounced determinate sentence to community service (TIG) for Category 2 offenders who confessed or who participated in physical violence without the intent to kill. It seems that a similar practice was also adopted for Category 1 offenders at Gacaca courts, though we do not have data regarding conversion of prison sentences to TIG in the domestic courts.

Consequently, the proportion of indeterminate sentences in the domestic courts is much higher than those in the ICTR or the Gacaca courts. This is partially due to the fact that most of these verdicts included in our database were handed out in the earlier years of the justice process, when the OL 08/96 governed genocide prosecutions. The OL 08/96 stipulated the death sentence as the mandatory sentence for all Category 1 defendants. The subsequent laws, however, provided judges with a possibility to hand out either life imprisonment or a death sentence for Category 1 offenders who did not plead guilty and reduced determinate sentences for those who pleaded guilty, as shown in Table $1 .{ }^{89}$

${ }^{89}$ See, e.g., Art. 68 OL 40/2000, Art. 72 16/2004. 
Restricting our analysis to determinate sentences, Figure 1 depicts the sentence lengths in each of the three jurisdictions. Specifically, the figure illustrates the percentages of determinate sentences falling between 1-5 years, 6-10 years, 11-15 years, 16-20, 21-25 years, and 26 years and above. The majority of those convicted at the ICTR and at Gacaca courts received determinate sentences, compared to only 32 defendants ( 22 percent) tried at the domestic courts included in our sample. Given the very limited number of these cases, these data must be interpreted with caution.

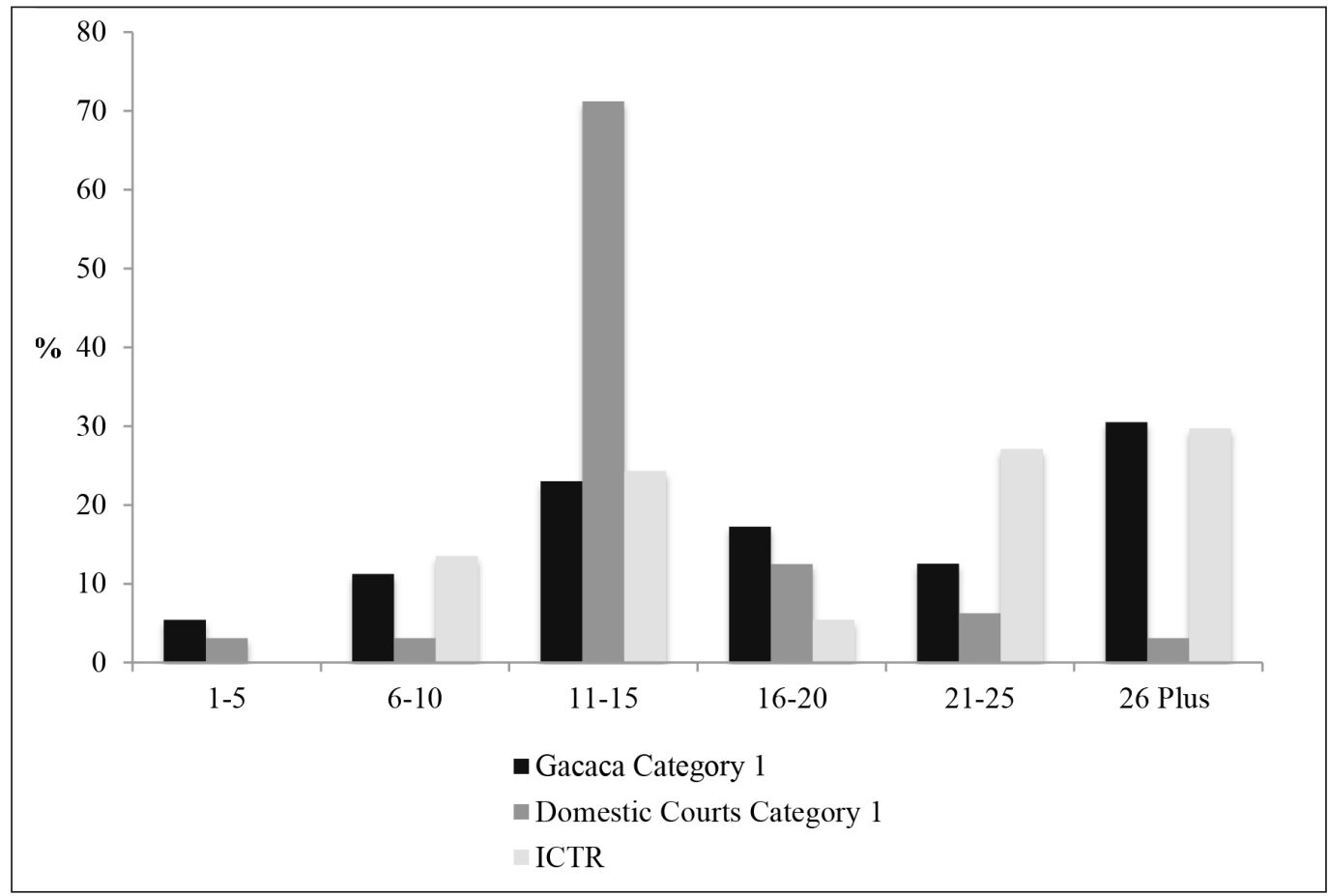

Figure 1. Determinate Sentence Lengths at the ICTR and in Rwandan Domestic and Gacaca Courts (sentences in years).

As seen in the figure, a small percentage of prison sentences given by the Gacaca courts and by the domestic courts were less than five years, while no sentences at the ICTR were this low. More than 10 percent of trials with determinate sentences given by both the ICTR and the Gacaca courts were between 6 and 10 years in prison, though the domestic courts had very few sentences in this range. The Rwandan domestic courts cases in our sample had the highest percentage of Category 1 trials - over 71 percent-resulting in a prison sentence between 11 and 15 years. In contrast, the highest percentage of those who received determinate sentences at the ICTR (29.7 percent) and at Gacaca (30.5 percent) were given relatively severe sentences (26 or more years in prison).

As of 2000, only Category 1 defendants who pleaded guilty or who were minors at the time of genocide were eligible for determinate sentences in Rwanda. In our sample of domestic court cases, 30 defendants confessed and two were minors at the time of the genocide. Additionally, all 30 defendants who pleaded guilty did so before being included on the list of genocide suspects and thus before the prosecution started. We do not have data on the proportion of people who confessed in the Gacaca courts, though we anticipate that the number of confessions was comparatively much higher in Gacaca courts given the public setting, the emphasis placed on conversation, and pre-trial sensitization efforts. That being said, the results suggest that the majority of Category 1 defendants at the Gacaca courts may have pleaded guilty only after being included on the list of genocide suspects, which would thus result in 25-30 years imprisonment if inyangamugayo followed the OLs.

In contrast, the ICTR judges regularly handed out relatively severe determinate sentences to those who did not plead guilty. Life imprisonment, as the maximum sentence, was reserved only 
for the most serious offenders ${ }^{90}$ convicted of crimes of the most heinous nature. ${ }^{91}$ This suggests that the ICTR judges may have been comparing those tried at the Tribunal against each other (rather than against all who participated in the genocide) and thus may have differentiated sentence length depending on culpability relative to other ICTR defendants.

Notably, Figure 1 also illustrates that judges in domestic courts and inyangamugayo in the Gacaca courts deviated from sentencing guidelines. Per the OLs, Category 1 defendants (who were not minors) could receive a sentence between 20 years and life in prison. ${ }^{92}$ The majority of determinate sentences for Category 1 crimes in our database, however, fall below 20 years, with many sentences at not even half the length dictated by law. It is impossible to determine the reasons for this divergence, as judges in Rwanda hardly presented any sentence-related reasoning in their judgments. Rugege and Karimunda observe a similar trend in their qualitative analysis of early genocide-related cases decided at domestic courts, noting that "Rwandan judges were too lenient in handling cases of genocide [...] and in some cases the discretion [of judges] was either misused or even abused in meting out overly lenient sentences..."93

\section{Category 2 Offenders at Domestic Courts and Gacaca}

Although we focus on Category 1 crimes in order to facilitate comparison between the ICTR, the domestic courts, and the Gacaca courts, we conclude by briefly analyzing Category 2 sentences in the domestic courts and in the Gacaca courts. ${ }^{94}$ We have data on 509 Category 2 trials with guilty verdicts in the domestic courts and 254,806 Category 2 trials with guilty verdicts in the Gacaca courts. The outcomes of these trials are shown in Table 4.

Almost 96 percent of Category 2 guilty verdicts in the Gacaca courts came with a determinate prison sentence, while only 56 percent of those in the domestic courts did. In line with this, over 42 percent of Category 2 cases with guilty verdicts at the domestic courts resulted in a life sentence, compared to only 2 percent of Gacaca court Category 2 cases. Gacaca courts did have a slightly higher median sentence length, though a full one-third of these sentences were commuted into a community service (Travail d'Interet General, or TIG). Taken together, this suggests that the Gacaca courts were comparatively more lenient with Category 2 sentencing. However, the more severe sentences at domestic courts may also be explained by legislative changes in the OLs, a progressive reduction of sentence severity over time, and the fact that the majority of Category 2 defendants in our domestic courts database were tried before the enactment of the OL 16/2004. Instead, almost 78 percent of the Category 2 cases tried at domestic courts in our sample were adjudicated under OL 08/96, which stipulated a mandatory sentence of life imprisonment if a defendant did not confess. ${ }^{95}$ In 2004, the OL 16/2004 provided for determinate sentences ranging from 5 to 30 years for Category 2 offenders (again depending on confession and their age).

In 2007, due to the inclusion of three sub-categories that were initially classified as Category 1 in Category 2 (i.e., notorious murderers, those who committed torture, and those who committed acts dehumanizing dead bodies), life imprisonment as an alternative to 30 years of imprisonment was again reintroduced as a possibility for Category 2 defendants in these subcategories. Consequently, due to these legislative changes entailing modification of the categories and prescribed sentences, we cannot conclusively say that Gacaca courts were more lenient than domestic courts, though future analyses of sentences over time will be able to address such questions.

\footnotetext{
${ }^{90}$ Prosecutor v. Nahimana, Barayagwiza, Ngeze, Judgment, December 3, 2003, ICTR-99-52, para. 1097.

${ }^{91}$ Prosecutor v. Elizaphan \& Gérard Ntakirutimana, Judgment, February 21, 2003, ICTR-96-10 \& ICTR-96-17, para. 773.

${ }^{92}$ Art. 72 OL 16/2004 as modified by OL 13/2008. According to the OL 40/2000 (the law which preceded the 2004 OL), the minimum sentence for Category 1 defendants was 25 years.

${ }_{93}$ Rugege and Karimunda, Domestic Prosecution of International Crimes, 91, 92.

${ }^{94}$ As noted above, the OL 08/96 initially divided all defendants into four categories. This was changed in 2004 when the OL 16/2004 combined Category 2 (those who participated in killings and those who caused injuries but acted with the intent to kill) and Category 3 (those who caused injuries and did not have the intent to kill) into a joint Category 2 encompassing all those who participated in offences against persons. Since our database also includes cases of Category 3 defendants decided under the OL 8/96, we have also included these in our analysis, though they would be Category 2 defendants under the final classification scheme. Thus, these cases are referred to as Category 2 in this article.

${ }^{95}$ Art. 14 OL 08/96.
} 
Table 4. Category 2 Sentencing Outcomes in Rwandan Domestic and Gacaca Courts.

\begin{tabular}{lccccccc}
\hline & $\begin{array}{c}\text { Median } \\
\text { Sentence }\end{array}$ & Range & $\begin{array}{c}\text { Determinate } \\
\text { Sentence (DS) }\end{array}$ & $\begin{array}{c}\text { Life } \\
\text { Sentence }\end{array}$ & $\begin{array}{c}\text { Death } \\
\text { Penalty }\end{array}$ & $\begin{array}{c}\text { Other } \\
\text { Sentence* }\end{array}$ & TIG \\
\hline & Years & Years & $\%$ & $\%$ & $\%$ & $\%$ & $\%$ \\
\hline $\begin{array}{l}\text { Domestic } \\
\text { Category 2 }\end{array}$ & 13 & $1-30$ & 56.4 & 42.4 & 0.8 & 0.4 & - \\
$\begin{array}{l}\text { Gacaca } \\
\text { Category 2 }\end{array}$ & 15 & $\begin{array}{l}3 \text { months } \\
-30 \text { years }\end{array}$ & 95.8 & 2.0 & NA & 2.2 & 32.7 \\
\hline
\end{tabular}

* Other sentences typically included paying victims or victims' families for property that was stolen.

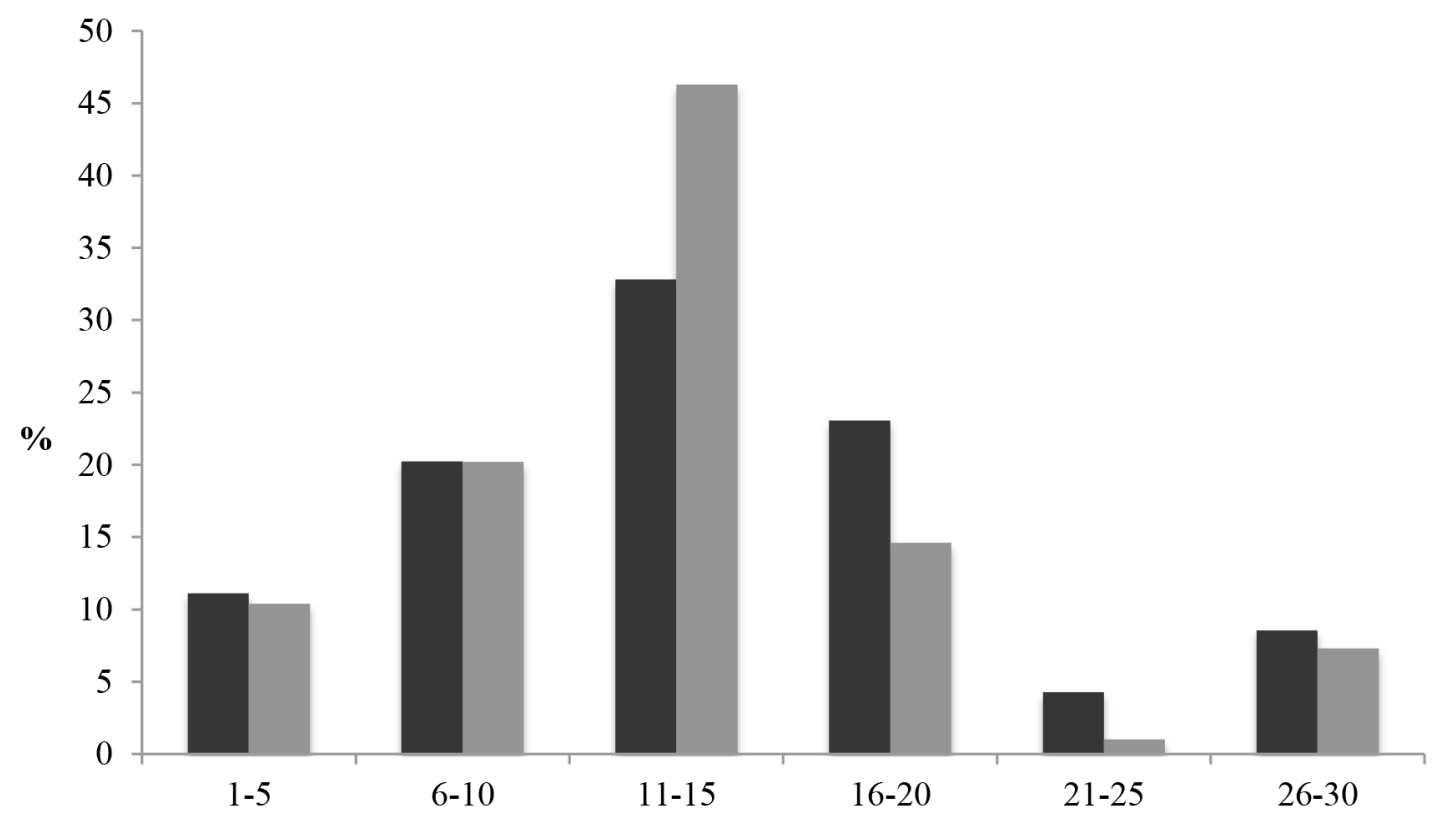

$$
\begin{aligned}
& \text { - Gacaca Category } 2 \\
& \text { - Domestic Courts Category } 2
\end{aligned}
$$

Figure 2. Category 2 Determinate Sentence Lengths in Domestic and Gacaca Courts (sentences in years).

Figure 2 illustrates determinate sentences for Category 2 guilty verdicts at the domestic courts and Category 2 guilty verdicts at the Gacaca courts. For both court systems, the distribution of determinate sentences is relatively similar. In fact, the domestic courts and Gacaca courts mirror each other in the proportion of determinate sentences that were 10 years or less, which were generally reserved for those who were convicted for causing an injury without intent to kill. As with Category 1 crimes, the domestic courts had a comparatively higher percentage of determinate sentences - over 46 percent -in the 11 to 15 year range. By contrast, Gacaca courts had higher percentages of sentences over 15 years, though there is also great similarity in the general distribution of sentences. While these differences might be related to the prevalence and timing of confessions, they may also indicate that Gacaca judges favored the imposition of determinate sentences over life imprisonment, even for those defendants who did not confess. This hypothesis would, however, require additional research, as we are unable to assess it on the basis of our data. 
This section has demonstrated that at all three levels of jurisdiction, judges employed a large variety of sentences to punish those convicted of genocide. Genocide - "the crime of crimes" - was certainly not punished with only the most severe sentences, which many would assume. Even though it is impossible to make conclusive claims due to the limitations of our data, it would seem that the most severe sentences were handed out at domestic courts in Rwanda. This, however, might also be explained by the fact that most of cases in our sample tried at domestic courts were decided under the OL 08/96, which dictated mandatory death sentences for Category 1 defendants and life imprisonment for Category 2 offenders who did not confess. Over time, the laws progressively introduced more lenient sentences for both groups, which was likely geared toward encouraging confessions. Unfortunately, we cannot evaluate whether an increasing number of defendants took advantage of these sentence reductions and pleaded guilty. However, given the intense sensitization campaigns and societal pressures on detainees to confess, we might also expect that to be the case.

\section{Conclusion}

This article aimed to compare sentencing laws and practices of those convicted of participation in the 1994 genocide in Rwanda. As over a million individuals were tried, the aftermath of the Rwandan genocide constitutes the most comprehensive case of criminal justice after atrocity. Three levels of criminal courts - an international, a domestic, and a localized - adjudicated genocide-related crimes, which makes the Rwandan case unique and a worthy case study of judicial responses to genocide.

We have shown that the sentencing of genocide developed into a rather sophisticated system internationally and domestically. At the ICTR, judges exercised much sentencing discretion and developed a sentencing approach relying on several factors to determine punishments. Apart from the seriousness of the crimes underlying convictions, the ICTR judges used the culpability of the defendants to distinguish the most serious offenders for the purposes of sentencing. The level of culpability was assessed by examining whether and how the defendant exercised authority and the role and degree of his/her involvement in atrocities. In Rwanda, the OLs governing the genocide-related trials introduced rather detailed sentencing guidelines and mandatory sentences. Offenders were divided into categories primarily depending on their level of culpability. Similar to the ICTR, the level of culpability was determined by the level of authority and the degree of the defendant's involvement in atrocities. The severity of mandatory sentences stipulated in the laws was gradated depending on the categorization of the defendant, which in turn depended on his/her level of culpability. Additionally, both domestic and Gacaca courts gave significant weight to those who confessed and apologized for their crimes, resulting in reduced sentences. In this sense, punishment for genocide in Rwanda did not only serve a retributive purpose, which was the main sentencing aim according to the ICTR judges ${ }^{96}$; it also incorporated other transitional justice goals, including truth-telling, reintegration of the offenders into their communities, and societal reconciliation according to the governing laws.

This article is also the first of its kind to compare sentencing practices across the three jurisdictional levels. Based on an unprecedented database, we have provided an overview of sentencing outcomes at the ICTR, Rwandan domestic courts, and the Gacaca courts. Due to the limitations of our data, we were only able to present basic descriptive statistics, and the results must be interpreted with caution. Again, while we gained access to the entire population of cases decided at the Gacaca courts and the ICTR, the domestic court cases were very difficult to collect, and the data are consequently rather limited. Keeping these limitations in mind, the analysis nonetheless demonstrated that sentences for genocide ranged from the most lenient to the most severe punishment within each of these court systems. It was certainly not the case that all of those found guilty were subjected to the most severe sentences.

Additionally, our results indicate that the domestic courts in Rwanda handed out more severe punishments compared to sentences issued at the ICTR and at the Gacaca courts. The vast majority

\footnotetext{
${ }^{96}$ See, for example, the most recent empirical study of the ICTY and ICTR sentencing, where the authors argue that the ICTY and ICTR sentences are exclusively predicted by factors relating to gravity and aggravating factors. Joseph W. Doherty and Richard H. Steinberg, "Punishment and Policy in International Criminal Sentencing: An Empirical Study," The American Journal of International Law 10, no. 1 (2016), 49-81.
} 
of cases at the domestic courts in our database were tried under the first OL 08/96 governing genocide prosecutions, which mandated very severe sentences. In this respect, sanctions envisaged for genocide-related crimes stipulated in the OL and applied by judges in Rwanda became less and less retributive over time. One of the reasons for this fade of retributivism might be the fact that next to eradicating the culture of impunity, Rwanda increasingly emphasized societal reconstruction, reconciliation, and the reintegration of perpetrators. These goals also explicitly governed the functioning of the Gacaca courts. In addition to these principled reasons, however, very pragmatic considerations - such as extremely overcrowded prisons, a backlog of genocide cases, and the economic and social repercussions of having a majority of the adult Hutu male population incarcerated-also likely contributed to these developments. The initial retributive sentiments underlying the first genocide laws combined with the fact that our domestic courts database includes predominantly early cases could thus be an explanation for relatively more severe sentences at domestic courts.

Notwithstanding, our results provide the first empirically-based indication that sentences issued at the ICTR seem to have been more lenient compared to those issued by domestic court in Rwanda. Since the ICTR tried those deemed most responsible for the most serious crimes committed during the genocide, this finding is largely counter-intuitive. In the early years of the ICTR's existence, many scholars speculated about the dangers of sentencing disparities between the ICTR and domestic courts ${ }^{97}$ and criticized the ICTR's initial sentencing as unfairly lenient. Our study is the first of its kind to provide an empirical foundation for these claims by systematically evaluating sentencing practices across the entire mandate of the Tribunal. Future research should further explore consistency of sentences across the three levels of justice and analyze the development of sentencing practices over time. Our analysis constitutes the first of its kind attempting to systematically analyze and compare punishment after the genocide in Rwanda and can serve as the starting point for further discussions and analyses of accountability mechanisms and punishment after atrocities.

\section{Bibliography}

Bornkamm, Paul Christoph. Rwanda's Gacaca Courts: Between Retribution and Reparation. New York: Oxford University Press, 2012. https://doi.org/10.1093/acprof:oso/9780199694471.001.0001

Chakravarty, Anuradha. Investing in Authoritarian Rule, Punishment and Patronage in Rwanda's Gacaca Courts for Genocide Crimes. New York: Cambridge University Press, 2015. https://doi.org/10.1017/CBO9781316018804

Clark, Phil. The Gacaca Courts, Post-Genocide Justiceand Reconciliation in Rwanda, Justicewithout Lawyers. New York: Cambridge University Press, 2010. https://doi.org/10.1017/CBO9780511761584

Cruvelier, Thierry. Court of Remorse, Inside the International Criminal Tribunal for Rwanda. Madison, Wisconsin: University of Wisconsin Press, 2006.

D'Ascoli, Silvia. Sentencing in International Criminal Law, The UN Ad Hoc Tribunals and Future Perspectives for the ICC. Oxford: Hart Publishing, 2011.

Des Forges, Alison. Leave None to Tell the Story, Genocide in Rwanda. New York: Human Rights Watch \& Federation Internationale des Ligues des Droits de L'Homme, Second Edition, 1999.

Doherty, Joseph W. and Steinberg, Richard H. "Punishment and Policy in International Criminal Sentencing: An Empirical Study." The American Journal of International Law 10, no. 1 (2016): 49-81. https://doi.org/10.5305/amerjintelaw.110.1.0049

Drumbl, Mark. "Rule of Law amid Lawlessness: Counselling the Accused in Rwanda's Domestic Genocide Trials." Columbia Human Rights Law Review 29 (1998): 545-640.

Drumbl, Mark. Atrocity, Punishment and International Law. New York: Cambridge University Press, 2007. https://doi.org/10.1017/CBO9780511611100

Gahima, Gerald. Transitional Justice in Rwanda, Accountability for Atrocity. New York: Routledge, 2013.

\footnotetext{
${ }^{97}$ See, for example, Madeleine H. Morris, "The Trials of Concurrent Jurisdiction: The Case of Rwanda," Duke Journal of Comparative \& International Law 7 (1996-1997), 363.
} 
Herik, Larissa van den. The Contribution of the Rwanda Tribunal to the Development of International Law. Amsterdam: VU University, Amsterdam, 2005.

Hola, Barbora, Catrien Bijleveld and Alette Smeulers. “Punishment for Genocide-Exploratory Analysis of ICTR Sentencing." International Criminal Law Review 11, no. 4 (2011): 745-773. https://doi.org/10.1163/157181211X587193

Hola, Barbora and Alette Smeulers. "ICTR and Rwanda-Facts and Figures." In Elgar Companion to the International Criminal Tribunal for Rwanda (ICTR), edited by Alette Smeulers and Annemarie de Brouwer. Glos: Edward Elgar Publishing Ltd., 2016 (forthcoming).

Hola, Barbora. International Sentencing - "Game of Russian Roulette" or Consistent Practice? Oisterwijk: BOXPress, 2012.

Human Rights Watch. Law and Reality. Progress in Judicial Reform in Rwanda. New York: Human Rights Watch, 2008.

Human Rights Watch. Rwanda: Justice after Genocide, 20 Years On. New York: Human Rights Watch, 2014.

International Crisis Group. Five Years after the Genocide in Rwanda: Justice in Question. ICG Report Rwanda No. 1, April 7, 1999.

Jones, Nikolas. The Courts of Genocide, The Politics and the Rule of Law in Rwanda and Arusha. New York: Routledge, 2009.

Kirkby, Coel. "Rwanda's Gacaca Courts: A Preliminary Critique." Journal of African Law 50, no. 2 (2006): 94-117. https://doi.org/10.1017/S0021855306000106

Meernik, James. "Proving and Punishing Genocide at the International Criminal Tribunal for Rwanda." International Criminal Law Review 4 (2004): 65-82. https://doi.org/ $\underline{10.1163 / 157181204773085948}$

Moghalu, Kingsley. Rwanda's Genocide, The Politics of Global Justice. New York: Palgrave Macmillan, 2005. https://doi.org/10.1057/9781403978387

Morris, Madeleine H. "The Trials of Concurrent Jurisdiction: The Case of Rwanda." Duke Journal of Comparative \& International Law" 7 (1996-1997): 349-374.

National Service of Gacaca Jurisdictions. Report on the Activities of the Gacaca Courts. Made available on June 18, 2012. On file with the authors.

Ngoga, Martin. Rwanda 10 Years After the Genocide: Creating Conditions for Justice and Reconciliation. Prosecutor's Colloqium, November 25-27, 2004. Accessed March 30, 2016. Doi: http://ictrarchive09.library.cornell.edu/ENGLISH/colloquium04/rwanda.html.

Nyseth Brehm, Hollie, Christopher Uggen, and Jean-Damascéne Gasanabo. "Genocide, Justice, and Rwanda's Gacaca Courts." Journal of Contemporary Criminal Justice 30, no. 3 (2014): 333352. https://doi.org/10.1177/1043986214536660

Palmer, Nicola. Courts in Conflict, Interpreting the Layers of Justice in Post-Genocide Rwanda. New York: Oxford University Press, 2015. https://doi.org/10.1093/acprof:oso/9780199398195.001.0001

Reyntjens, Filip. Political Government in Post-Genocide Rwanda. New York: Cambridge University Press, 2013. https://doi.org/10.1017/CBO9781107338647

Republic of Rwanda: Supreme Court: RAPORO, Y'IBIKORWA BY'URWEGO RW'UBUCAMANZA, Kigali: Republic of Rwanda, 2004-2011, 2011-2012, 2012-2013.

Rugege, Sam and Aime M. Karimunda. "Domestic Prosecution of International Crimes: The Case of Rwanda," In Africa and the International Criminal Court. edited by Gerhard Werle et al., 80-113. The Hague: International Criminal Justice Series 1, T.M.C. Asser Press, 2014. https://doi.org/10.1007/978-94-6265-029-9 7

Straus, Scott. "How Many Perpetrators Were There in the Rwandan Genocide? An Estimate." Journal of Genocide Research 6, no. 1 (2004): 85-98. https://doi.org/10.1080/14623520420001 94728

Tertsakian, Carina. Le Chateau, The Lives of Prisoners in Rwanda. London: Arves Bookes, 2008.

United Nations Outreach Programme on the Rwanda Genocide and the United Nations, Justice and Reconciliation in Rwanda. Background Note (2012). Accessed April 1, 2016. http://www. un.org/en/preventgenocide/rwanda/about/bgjustice.shtml. 


\section{Laws and Statutes}

Security Council, Resolution 955 (1994), November 8, 1994, UN Doc. S/RES/ 955 (1994).

Statute of the International Criminal Tribunal for Rwanda, S.C. Res. 955, UN Doc S/RES/955.

Rules of Procedure and Evidence of the International Criminal Tribunal for Rwanda. Adopted on June 29, 1995, as amended.

Organic Law 08/96 on the Organization of Prosecutions for Offences Constituting the Crime of Genocide or Crimes against Humanity Committed since October 1, 1990. Adopted on August 30, 1996.

Organic Law 40/2000 Setting Up Gacaca Jurisdictions and Organizing Prosecutions for Offences Constituting the Crime of Genocide or Crimes against Humanity Committed Between October 1, 1990 and December 31, 1994. Adopted on January 26, 2001.

Organic Law 07/2004 Determining the Organization, Functioning and Jurisdiction of Courts in Republic of Rwanda. Adopted on February 1, 2004.

Organic Law 16/2004 of 19/6/2004 Establishing the Organization, Competence and Functioning of Gacaca Courts Charged with Prosecuting and Trying Perpetrators of the Crime of Genocide and Other Crimes against Humanity, Committed between October 1, 1990 and December 31, 1994. Adopted on June 19, 2004.

Organic Law 10/2007 of 01/03/2007 Modifying and Complementing Organic Law 16/2004 of 19/6/2004 Establishing the Organization, Competence and Functioning of Gacaca Courts Charged with Prosecuting and Trying Perpetrators of the Crime of Genocide and Other Crimes against Humanity, Committed between October 1, 1990 and December 31, 1994. Adopted on March 1, 2007.

Organic Law 31/2007 Relating to the Abolition of the Death Penalty. Adopted on July 25, 2007.

Organic Law 13/2008 Modifying and Complementing OL 16/2004 of 19/6/2004 Establishing the Organization, Competence and Functioning of Gacaca Courts Charged With Prosecuting and Trying Perpetrators of the Crime Of Genocide And Other Crimes Against Humanity, Committed between October 1, 1990 and December 31, 1994. Adopted on May 19, 2008. 